Basic Health Sciences

Poster

Abstract ID: 122

\title{
The investigation of cytotoxic effects of Cinnamomum zeylanicum on human breast cancer cell line (MCF-7)
}

Ainatun Natrah Azmi ${ }^{a}$ | Widya Abd Wahab ${ }^{a}$ | Noor Hasniza Md Zin ${ }^{a} \mid$ Noraslinda Muhamad Bunnori ${ }^{a} \mid$ Normah Haron ${ }^{\mathrm{a}}$

${ }^{a}$ Kulliyyah of Science, International Islamic University Malaysia

Introduction: Cinnamon is one of the oldest herbal medicines that has been traditionally used as flavouring agent, insecticidal, antifungal and also as tooth powder to treat dental problems. Nowadays cinnamon is used in pharmaceutical preparations, perfume production, chemical industry and food industry as seasonings. In this study, the cytotoxicity of the cinnamon extracts towards human breast cancer cell line (MCF-7) was investigated. Methods: Cinnamomum zeylanicum was extracted using Soxhlet extraction method with methanol as the solvent, producing $7.06 \%$ of yield extract. The extract was analysed using gas chromatography/ mass spectrometry (GCMS). Results: The result showed that cinnamaldehyde was the major constituent, forming $74.14 \%$ of the total constituents. The cytotoxicity of $C$. zeylanicum extract against MCF-7 was determined through colorimetric $M T$ assay. It was demonstarted that the $\mathrm{IC}_{50}$ of extracts at 24 hours and 48 hours of incubation period was $48 \mu \mathrm{g} / \mathrm{ml}$ and $140 \mu \mathrm{g} / \mathrm{ml}$ respectively. Conclusions: The cinnamon methanolic extract possess cytotoxic effects on human breast cancer cell lines.

KEYWORDS: cinnamon extract, breast cancer cell MCF7 